\title{
ON A JENSEN-TYPE INEQUALITY FOR GENERALIZED $f$-DIVERGENCES AND ZIPF-MANDELBROT LAW
}

\author{
ĐildA PEČARIĆ, JOSIP PEČARIĆ AND MIRNA Rodić
}

Abstract. By means of one new Jensen-type inequality for signed measures which is characterized via several different Green functions, in this paper we derive new inequalities for generalized $f$-divergences. The applications on the Zipf-Mandelbrot law, as one specific kind of probability distributions, are also given. Mathematics subject classification (2010): 26D15, 60E05, 94A17.

Keywords and phrases: Green function, Jensen inequality, $f$-divergence, Zipf-Mandelbrot law.

\section{REFERENCES}

[1] I. CSISZÁR, Information measures: A critical survey, Trans. 7th Prague Conf. on Info. Th., Statist. Decis. Funct., Random Processes and 8th European Meeting of Statist., Volume B, 73-86, Academia Prague 1978.

[2] I. CSISZÁR, Information-type measures of difference of probability distributions and indirect observations, Studia Sci. Math. Hungar. 2, 1967, 299-318.

[3] S. S. Dragomir, Some inequalities for the Csiszár $\phi$-divergence when $\phi$ is an L-Lipschitzian function and applications, Ital. J. Pure Appl. Math., 15, 2004, 57-76.

[4] L. Horváth, Đ. PeČArić And J. PeČArić, Estimations of $f$ - and Rényi divergences by using a cyclic refinement of the Jensen's inequality, J. Bull. Malays. Math. Sci. Soc. 2017, https://doi.org/10.1007/s40840-017-0526-4.

[5] J. JAKŠEtiĆ, Đ. PeČARIĆ AND J. PeČARIĆ, Some properties of Zipf-Mandelbrot law and Hurwitz $\zeta$-function, Math. Inequal. Appl. 21 (2), 2018, 575-584.

[6] J. N. KAPUR, A comparative assessment of various measures of directed divergence, Advances in Management Studies, vol. 3, 1984, 1-16.

[7] S. KullBaCk, Information Theory and Statistics, J. Wiley, New York, 1959.

[8] S. Kullback AND R. A.Leibler, On information and sufficiency, Annals Math. Statist. 12, 1951, $79-86$.

[9] F. Liese And I. Vajda, Convex Statistical Distances (Teubner-Texte Zur Mathematik), vol. 95, Teubner, Leipzig, Germany, 1987.

[10] R. MikiĆ, Đ. PEČARIĆ AND J. PEČARIĆ, Inequalities of the Jensen and Edmundson-LahRibarič type for 3-convex functions with applications, J. Math. Inequal. 12, 3, 2018, 677-692, dx.doi.org/10.7153/jmi-2018-12-52.

[11] Đ. PeČArIĆ, J. PeČARIĆ And D. PoKAZ, Generalized Csiszár's $f$-divergence for Lipschitzian functions, Math. Inequal. Appl., accepted.

[12] Đ. PEČARIĆ, J. PEČARIĆ AND M. Rodić, About the sharpness of the Jensen inequality, J. Inequal. Appl. (2018), 2018:337, https://doi.org/10.1186/s13660-018-1923-4.

[13] J. PeČARIĆ, I. PERIĆ AND M. Rodić LipAnović, Uniform treatment of Jensen type inequalities, Math. Reports 16 (66), 2, 2014, 183-205.

[14] J. PEČARIĆ AND M. Rodić, Uniform treatment of Jensen type inequalities II, Math. Reports, 21 (71), $3,2019$.

[15] A. RenYi, On measures of entropy and information, Proc. Fourth Berkeley Symp. Math. Statist. Prob. Vol 1, University of California Press, Berkeley, 1961.

[16] I. VAJDA, Theory of Statistical Inference and Information, Kluwer, Dordrecht, 1989. 